\title{
MODEL GAYABERAT 2D UNTUK MENGUNGKAP STRUKTUR GEOLOGI BAWAH PERMUKAAN PADA DAERAH PANAS BUMI NATAR
}

\section{D CONCEPTUAL MODEL ON NATAR GEOTHERMAL SYSTEM BASED ON GRAVITY DATA}

\author{
Bella Restu Juliarka dan Mochamad lqbal \\ Kelompok Keahlian Geologi, Teknik Geologi, Institut Teknologi Sumatera \\ mochamad.iqbal@gl.itera.ac.id
}

\begin{abstract}
ABSTRAK
Daerah panas bumi Natar terletak di Kecamatan Natar yang berjarak kurang lebih $10 \mathrm{~km}$ utara Bandar Lampung, Provinsi Lampung. Lapangan panas bumi ini terbilang cukup unik karena manifestasi mata air panas yang muncul ke permukaan berada pada daerah yang relatif datar. Pengamatan geologi pada singkapan untuk mengetahui struktur geologi yang mengontrol keluarnya air panas tersebut sulit dilakukan karena terbatasnya singkapan batuan sehingga diperlukan metode geofisika untuk menginterpretasi kondisi bawah permukaan seperti metode gayaberat. Geologi daerah penelitian ditutupi oleh Formasi Lampung yang terdiri dari batuan piroklastik-vulkanoklastik dengan tebal mencapai $200 \mathrm{~m}$. Hasil pemrosesan data gayaberat menunjukkan nilai anomali Bouguer yang berkisar antara 51,0-62,6 mGal. Hasil interpretasi peta anomali Bouguer memperlihatkan keberadaan lima struktur sesar, yang menjadi jalur keluarnya air panas, yang dominan berarah baratlaut-tenggara dan utara-selatan. Arah tersebut menandakan bahwa struktur geologi yang terdapat pada daerah penelitian masih berkaitan dengan Sesar Besar Sumatera yang juga berarah baratlaut-tenggara. Pemodelan 2D bawah permukaan yang dilakukan dengan menggunakan perangkat lunak 'Oasis Montaj 8.4', menghasilkan tiga lapisan densitas batuan yaitu densitas yang berasosiasi dengan Formasi Lampung dengan densitas $1,9 \mathrm{~g} / \mathrm{cm}^{3}$, dan yang berasosiasi dengan dua struktur basement dengan densitas masing-masing $2,54 \mathrm{~g} / \mathrm{cm}^{3}$ dan $2,76 \mathrm{~g} / \mathrm{cm}^{3}$, yang membentuk struktur seperti horst dan graben. Pengeboran eksplorasi untuk penelitian selanjutnya disarankan dilakukan pada sebelah barat mata air panas untuk mengonfirmasi model bawah permukaan.
\end{abstract}

Kata kunci: gayaberat, geotermal, Lampung, Natar, struktur geologi

\section{ABSTRACT}

The Natar geothermal field is located in Natar District, which is approximately $10 \mathrm{~km}$ north of Bandar Lampung, Lampung Province. This geothermal area is unique because the manifestation of hot springs that appear on the surface is in a relatively flat area. Geological observations on outcrops to determine the geological structure that control the hot springs are difficult to carry out due to limited rock outcrops, so geophysical methods are needed to interpret subsurface conditions such as gravity methods. The geology of the study area is covered by Lampung Formation consists of pyroclastic - volcaniclastic rocks with thickness reaching $200 \mathrm{~m}$. The result of gravity data processing shows the value of Bouguer anomaly which ranges from 51.0 to $62.6 \mathrm{mGal}$. The interpretation of Bouguer's anomaly data shows five fault structures predominate northwest-southeast and north-south trend, which act as the water path discharge. This trend indicates that the geological structure in the study area is still related to the Great Sumatran Fault, which is also trending northwest-southeast. The $2 D$ subsurface modeling is conducted by using Oasis Montaj software 8.4 produces three layers of rock density, namely a layer associated to the Lampung Formation with density of $1.9 \mathrm{~g} /$ $\mathrm{cm}^{3}$, and two layer basements with densities of $2.54 \mathrm{~g} / \mathrm{cm}^{3}$ and $2.76 \mathrm{~g} / \mathrm{cm}^{3}$ respectively, 
forming horst and graben like structures in the study area. Exploration drilling for further research is recommended to the west of the hot springs to confirm the subsurface model.

Keywords: gravity, geothermal, geological structure, Lampung, Natar

\section{PENDAHULUAN}

Lapangan panas bumi Natar terletak di Kabupaten Lampung Selatan, sekitar $10 \mathrm{~km}$ utara Kota Bandar Lampung. Pada lapangan ini terdapat dua kelompok mata air panas, yaitu mata air panas Natar (MAP Natar) dan mata air panas Cisarua (MAP Cisarua) dengan potensi spekulatif $25 \mathrm{MWe}$ (Ditjen EBTKE, 2017).

Penelitian tentang geokimia air yang dilakukan oleh lqbal dkk. (2019) menunjukkan bahwa MAP Natar dan MAP Cisarua memiliki temperatur $45-54^{\circ} \mathrm{C}$ dengan $\mathrm{pH}$ netral, bertipe bikarbonat-steam heated water (kondensasi uap geotermal ke air tanah dangkal), dan berasal dari air meteorik. Perhitungan geotermometer menunjukkan bahwa lapangan panas bumi di Natar tergolong ke sistem temperatur sedang yaitu $120-140^{\circ} \mathrm{C}$ dengan kedalaman reservoir diperkirakan sekitar 285-400m (Iqbal dkk., 2019b). Sistem dengan entalpi sedang juga dapat dimanfaatkan untuk pembangkit listrik dengan menggunakan teknologi binary cycle ataupun dapat digunakan sebagai pemanfaatan langsung seperti pengering kopi, tomat, pisang maupun pendingin ruangan tergantung kebutuhan yang ada di daerah sekitar (Saptadji, 2018). Selain itu, data isotop stabil menunjukkan bahwa MAP Natar dan MAP Cisarua merupakan air tanah modern (yang meresap kurang dari 10 tyl) dan mengalami interaksi dengan batuan metamorf-karbonat di bawah permukaan (lqbal dkk., 2019b).

Berdasarkan analisis dari morfologi dan cekungan air tanah, sistem panas bumi Natar termasuk ke dalam Cekungan Air Tanah (CAT) Metro-Kotabumi, dengan wilayah daerah resapan yaitu berada pada bagian barat di sekitar kaki perbukitan barisan dan pada bagian selatan di sekitar kaki Gunung Betung dan Pesawaran (Iqbal dkk., 2019a).
Kemunculan MAP Natar dan MAP Cisarua ini tergolong cukup unik dibandingkan mata air panas di daerah yang biasanya muncul di sekitar gunung api. MAP Natar dan MAP Cisarua muncul pada daerah yang relatif datar dan jauh dari gunung api sehingga perlu dilakukan penelitian untuk mengetahui penyebab keluarnya MAP Natar dan MAP Cisarua ini.

Penelitian ini menggunakan metode gayaberat (gravity) dengan tujuan untuk mengungkap keberadaan struktur geologi bawah permukaan yang mengontrol keluarnya MAP Natar dan MAP Cisarua. Pengukuran gayaberat di dalam investigasi dan aplikasi pada bidang kebumian telah dilakukan sejak tahun 1940an (Rymer, 2016). Pada sektor geotermal, pengukuran gayaberat dapat dilakukan untuk melakukan pemodelan 2D, 3D, dan mengetahui struktur geologi bawah permukaan (Guglielmetti dkk., 2013; Maithya dkk., 2020; Pocasangre dkk., 2020; Soengkono dkk., 2013; Uwiduhaye dkk., 2018).

Metode geofisika gayaberat dipilih karena topografi daerah penelitian yang relatif datar sehingga analisis struktur geologi dari singkapan di permukaan sulit untuk dilakukan. Metode gayaberat dilakukan dengan cara mengukur medan gravitasi bumi dan menggunakan variasi gaya gravitasi tersebut untuk menginterpretasi geologi bawah permukaan berdasarkan kontras densitas batuan (Uwiduhaye dkk., 2018). Penelitian ini diharapkan dapat membantu pengembangan potensi panas bumi yang ada di daerah penelitian.

\section{GEOLOGI}

Secara umum, geologi daerah penelitian tercakup dalam peta geologi regional lembar Tanjungkarang (Gambar 1). Daerah penelitian disusun oleh beberapa satuan/formasi batuan dari tua ke muda sebagai berikut (Mangga dkk., 1993): 
- Batupualam Trimulyo (Pzgm) terdiri dari batupualam/marmer dan sekis yang berumur Paleozoikum. Formasi ini merupakan batuan dasar di daerah penelitian. Tersingkap sedikit pada bagian utara daerah penelitian.

- Granodiorit Branti (Kgdb) merupakan granodiorit berbutir sedang yang tersusun atas biotit subhedral. Satuan ini muncul pada bagian utara daerah penelitian yang berumur $87 \pm 3$ jtl (Kapur).

- Formasi Lampung (QTI) yang tersusun dari tuf, tuf pumisan, dan batupasir tufan. Tuf berwarna putih sampai kecoklatan berkomposisi riolit, dan terkekarkan di beberapa tempat. Tuf pumisan berwarna kelabu dengan butir sedang-kasar, terpilah buruk, dan tersusun atas pumis dan fragmen batuan. Batupasir tufan berwarna putih kekuningan dengan butir halus-sedang, terpilah buruk, membundar tanggung, terdapat fragmen pumis dan tidak kompak, di beberapa tempat memperlihatkan struktur silang siur.
Formasi ini memiliki tebal sekitar $200 \mathrm{~m}$, diendapkan pada lingkungan daratfluvial, air payau.

- Satuan Endapan Gunungapi Muda (Qhpv) merupakan satuan termuda di daerah penelitian yang menindih secara tidak selaras Formasi Lampung. Di daerah penelitian, satuan ini merupakan hasil endapan gunungapi Betung yang berumur Kuarter yang tersusun atas lava (andesit-basalt), breksi, dan tuf.

Daerah penelitian didominasi oleh kelurusan yang berarah baratlaut-tenggara dan searah dengan arah dari Sesar Besar Sumatera (Great Sumatran Fault). Sesar Lampung-Panjang yang berada di dekat daerah penelitian diperkirakan masih dipengaruhi oleh sesar tersebut. Di dalam daerah pengukuran gayaberat, terdapat satu kelurusan yang berarah timurlautbaratdaya yang diduga menjadi pengontrol keluarnya mata air panas Natar. Hasil dari penelitian gayaberat ini diharapkan dapat mempertegas kelurusan tersebut.

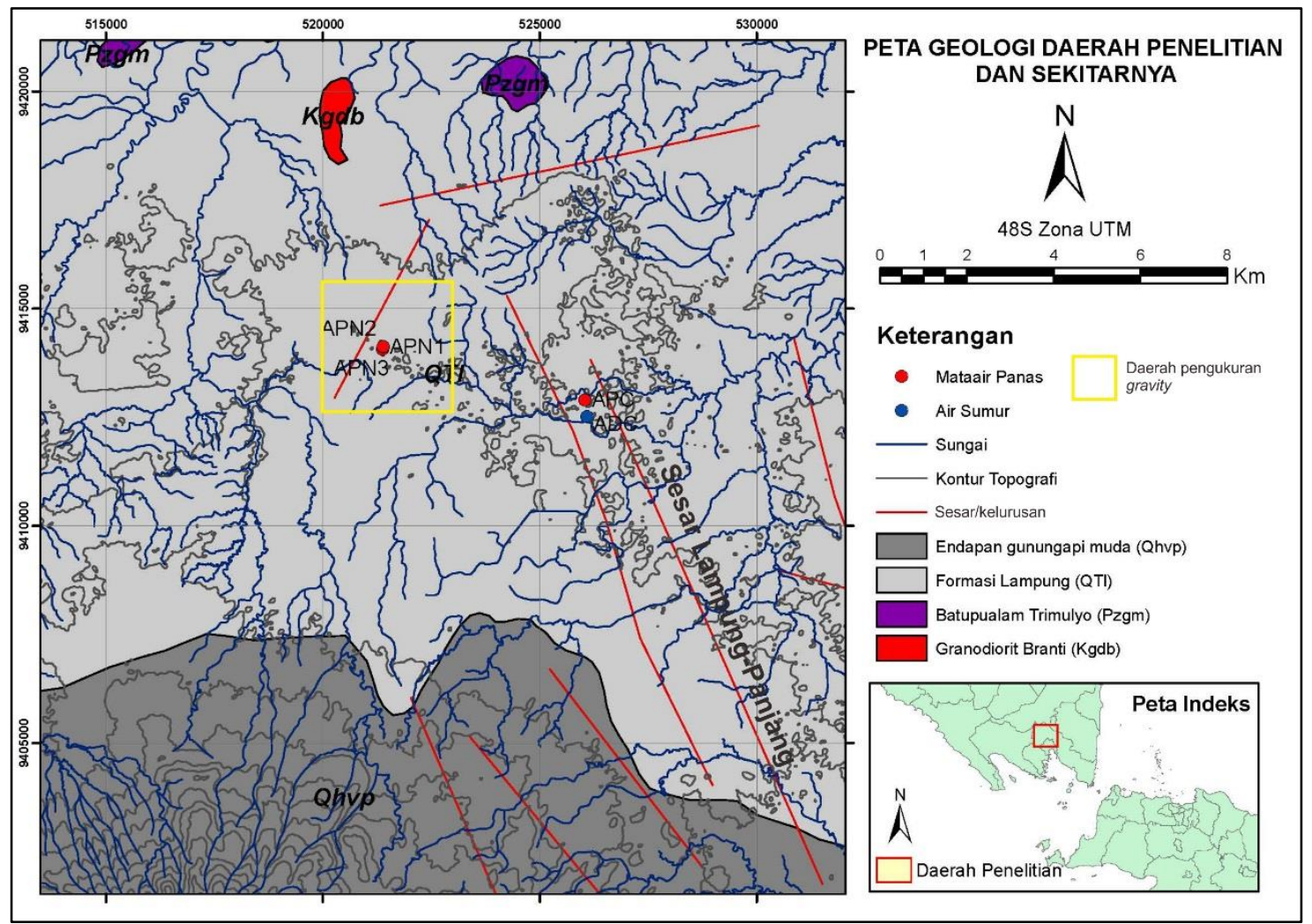

Gambar 1. Peta geologi daerah penelitian, lembar Tanjung Karang

(modifikasi dari Mangga dkk., 1993) 


\section{MAKALAH ILMIAH}

\section{METODOLOGI}

Lokasi daerah penelitian terletak di sekitar mata air panas Natar di Jalan Lintas Sumatra/Jalan Raya Natar dan secara administratif masuk ke dalam Kecamatan Natar, Kabupaten Lampung Selatan. Akuisisi data menggunakan metode geofisika yaitu metode gayaberat untuk mengetahui gambaran struktur geologi di bawah permukaan yang menyebabkan munculnya mata air panas Natar. Objek penelitian pada penelitian ini adalah lokasi sekitar mata air panas Natar seluas $2,5 \mathrm{~km} \times 2,5 \mathrm{~km}$ dan sebanyak 81 titik yang mencakup daerah penelitian (Gambar 2).

Akuisisi data gayaberat dilakukan dengan menggunakan gravitymeter tipe CG-6 yang disewa dari Laboratorium Teknik Geofisika Institut Teknologi Sumatera, sedangkan pemodelan bawah permukaan dilakukan dengan menggunakan perangkat lunak Geosoft Oasis Montaj 8.4. Pengukuran menggunakan sistem looping yang bertujuan untuk memperoleh nilai koreksi apung alat (drift) yang disebabkan oleh guncangan alat selama berjalan sehingga terjadi perubahan pembacaan nilai gravitymeter dengan cara membandingkan dengan nilai Gayaberat absolut pada suatu titik ikat (base station). Pengukuran nilai gayaberat yang dilakukan pada penelitian ini menggunakan base station yang ada di Universitas Lampung dengan nilai yang tertera pada Tabel 1.

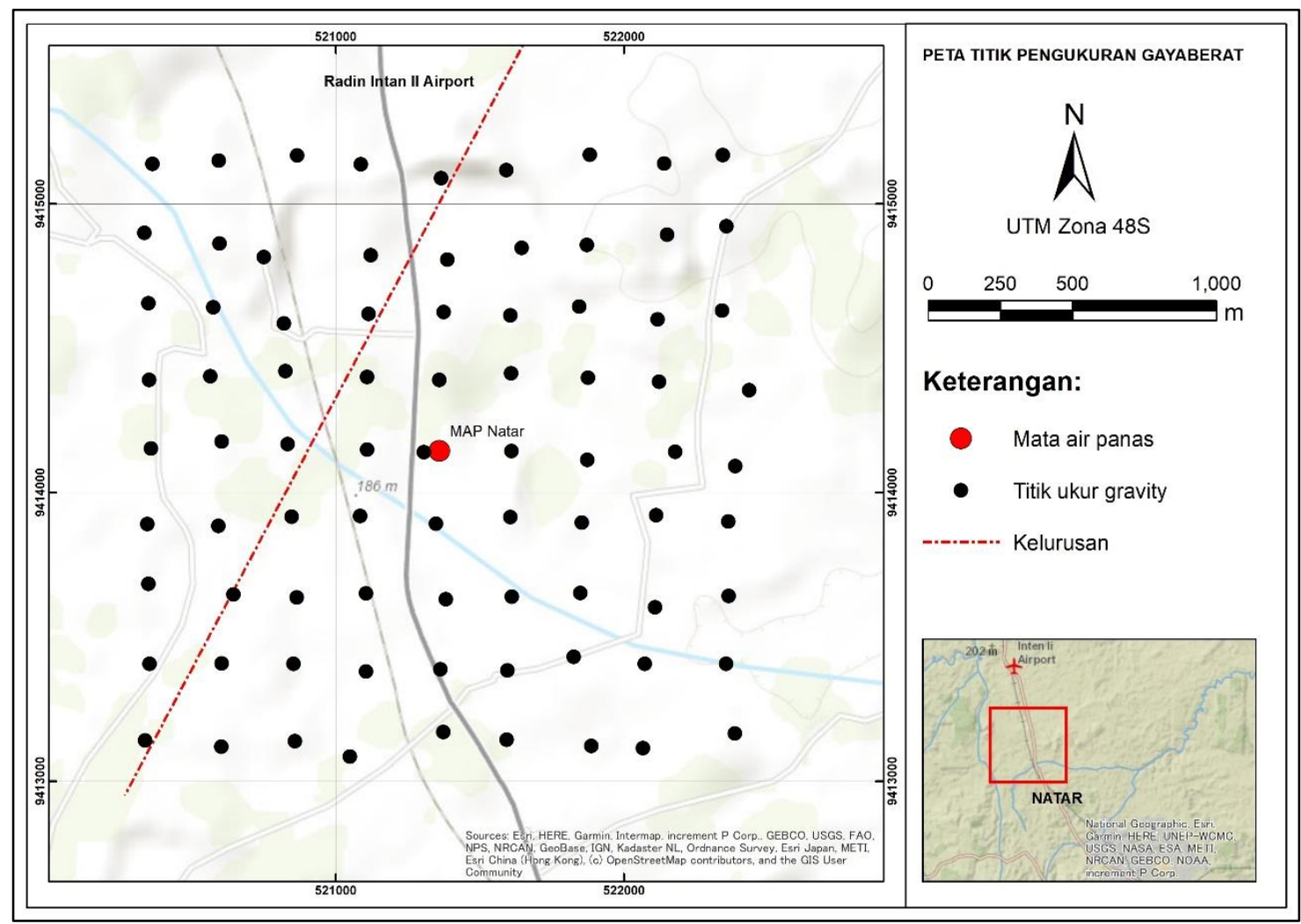

Gambar 2. Titik pengukuran gayaberat

Tabel 1. Nilai gayaberat absolut pada titik ikat (base station)

\begin{tabular}{|c|c|c|c|c|}
\hline \multicolumn{3}{|c|}{ Koordinat } & \multirow{2}{*}{$\begin{array}{l}\text { Nilai Gayaberat } \\
\text { absolut (mGal) }\end{array}$} & \multirow{2}{*}{$\begin{array}{c}\text { Waktu } \\
\text { pengukuran }\end{array}$} \\
\hline Lin & Bujur & Elevasi (m) & & \\
\hline $05^{\circ} 22,02^{\prime} \mathrm{S}$ & $105^{\circ} 14,43^{\prime} \mathrm{E}$ & 143,6 & 978101,21 & Juli 2003 \\
\hline
\end{tabular}


Data gayaberat mentah dikoreksi untuk menghasilkan anomali Bouguer dengan menerapkan koreksi standar di setiap stasiun. Gambar 3 memperlihatkan diagram alir pemrosesan data gayaberat yang dilakukan pada penelitian ini. Estimasi densitas untuk koreksi data penelitian ini yaitu 2,47 $\mathrm{g} / \mathrm{cm}^{3}$ dengan menggunakan metode Parasnis (Parasnis dan Cook, 1952). Densitas ini digunakan dalam koreksi Bouguer dan koreksi medan terhadap data gayaberat yang diamati (Uwiduhaye dkk., 2018).

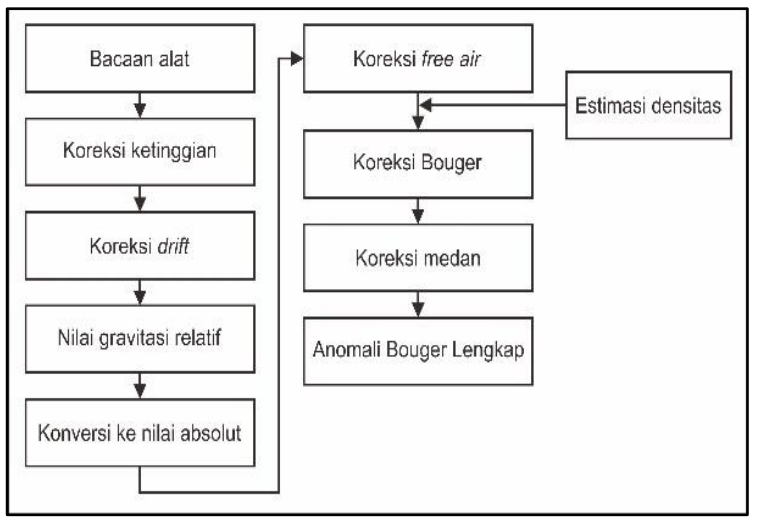

Gambar 3. Diagram alir pemrosesan data gayaberat

Tujuan akhir dari koreksi gayaberat adalah untuk menghitung anomali Bouguer. Dari prosedur di atas, anomali Bouguer dapat dihitung dari persamaan berikut (Maithya dkk., 2020; Uwiduhaye dkk., 2018):

$$
\Delta g=g_{o b s}-\gamma+\beta h-2 \pi G \rho h-\rho T
$$

dengan $\Delta \mathrm{g}$ adalah anomali Bouguer ( $\mathrm{mGal}$ ), gobs nilai gayaberat teramati, $Y$ nilai gayaberat normal (mGal), $\beta \mathrm{h}$ nilai koreksi bebas ( $\mathrm{mGal}$ ), $\mathrm{h}$ adalah elevasi $(\mathrm{m}), \mathrm{G}$ nilai gayaberat konstan, $\rho$ nilai estimasi densitas $\left(\mathrm{g} / \mathrm{cm}^{3}\right), 2 \pi \mathrm{G} p h$ merupakan nilai koreksi bouguer (mGal), dan $\rho T$ merupakan nilai koreksi medan (mGal).
Anomali Bouguer disebabkan oleh heterogenitas dari distribusi densitas batuan di bawah permukaan (Uwiduhaye dkk., 2018). Setelah diperoleh anomali Bouguer, langkah selanjutnya yaitu melakukan gridding data agar menghasilkan peta dengan beragam penerapan filter sebelum interpretasi dilakukan. Pada penelitian ini, salah satu filter yang digunakan untuk melihat struktur bawah permukaan yaitu filter secondary vertical derivative (SVD).

Setelah gridding data gayaberat dilakukan, langkah berikutnya adalah memisahkan anomali Bouguer menjadi komponenkomponen regional dan residual. Pemisahan residual dan regional dilakukan sebelum analisis dan interpretasi data lebih lanjut. Gambar 4 memperlihatkan diagram alir dalam analisis data gayaberat.

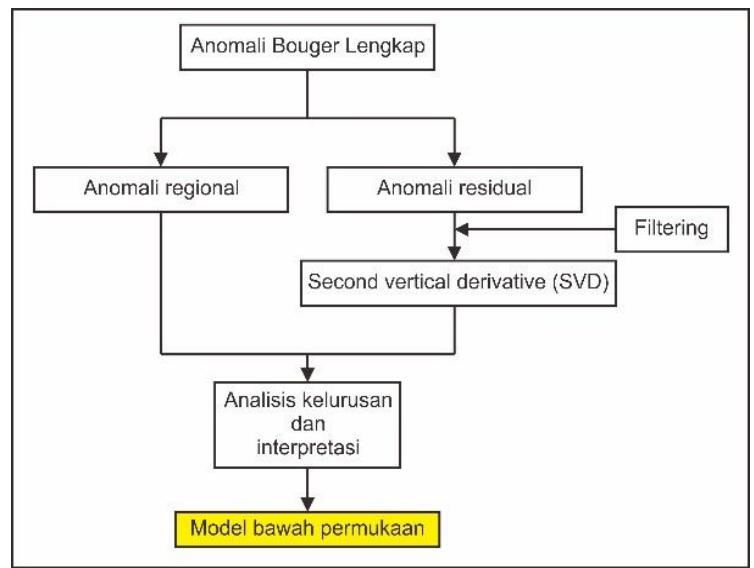

Gambar 4. Diagram alir analisis data gayaberat

\section{HASIL}

Dari hasil gridding data gayaberat, penulis menghasilkan empat peta anomali gayaberat yang digunakan untuk interpretasi struktur bawah permukaan yaitu peta anomali Bouguer, peta anomali regional, peta anomali residual, dan peta SVD (Gambar 5). 


\section{MAKALAH ILMIAH}

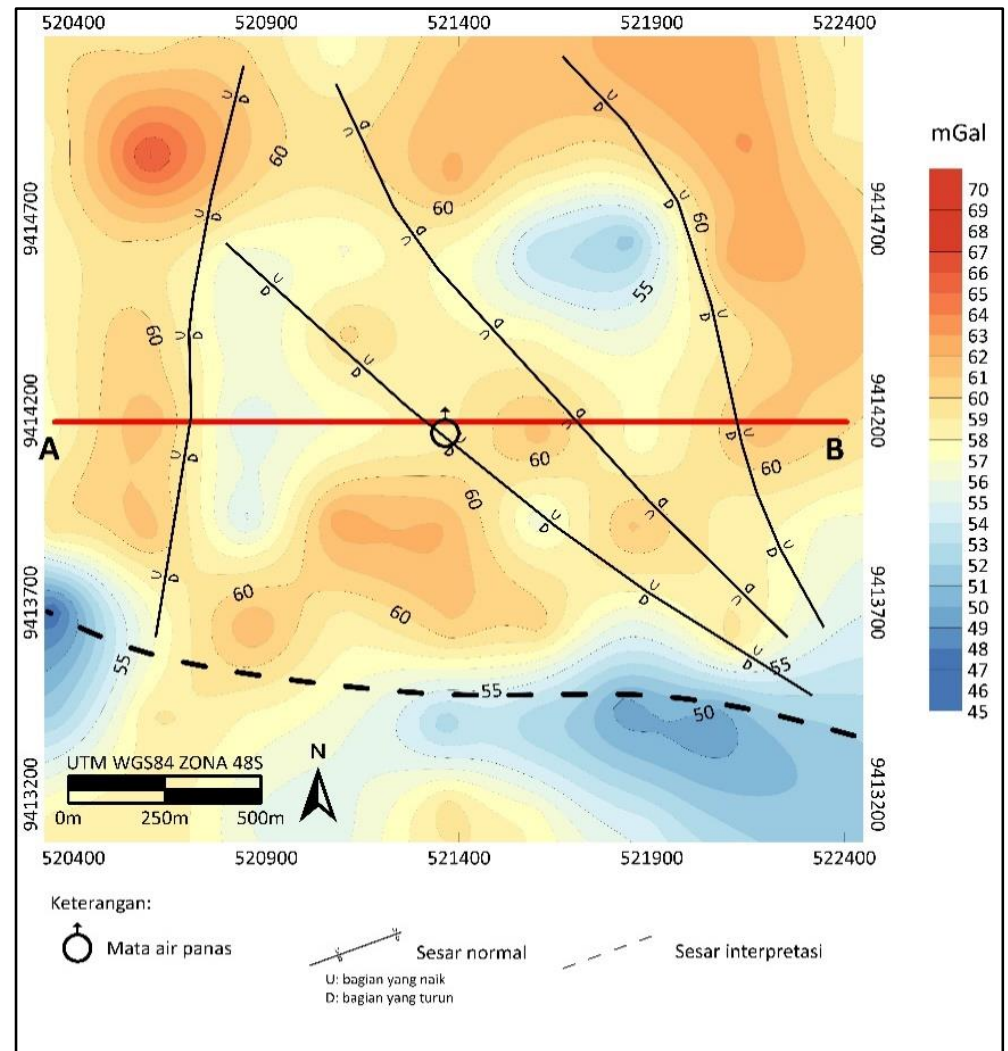

(a)

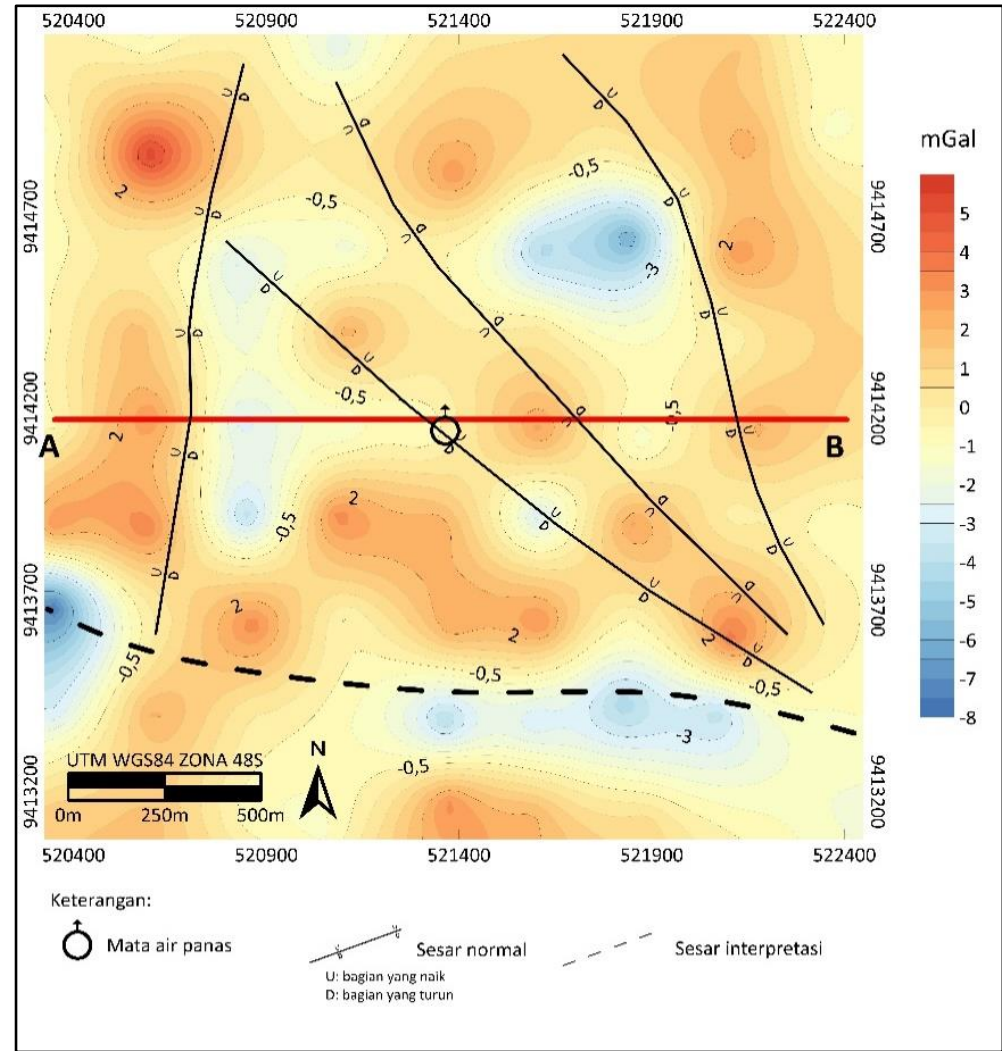

(b) 


\section{MAKALAH ILMIAH}

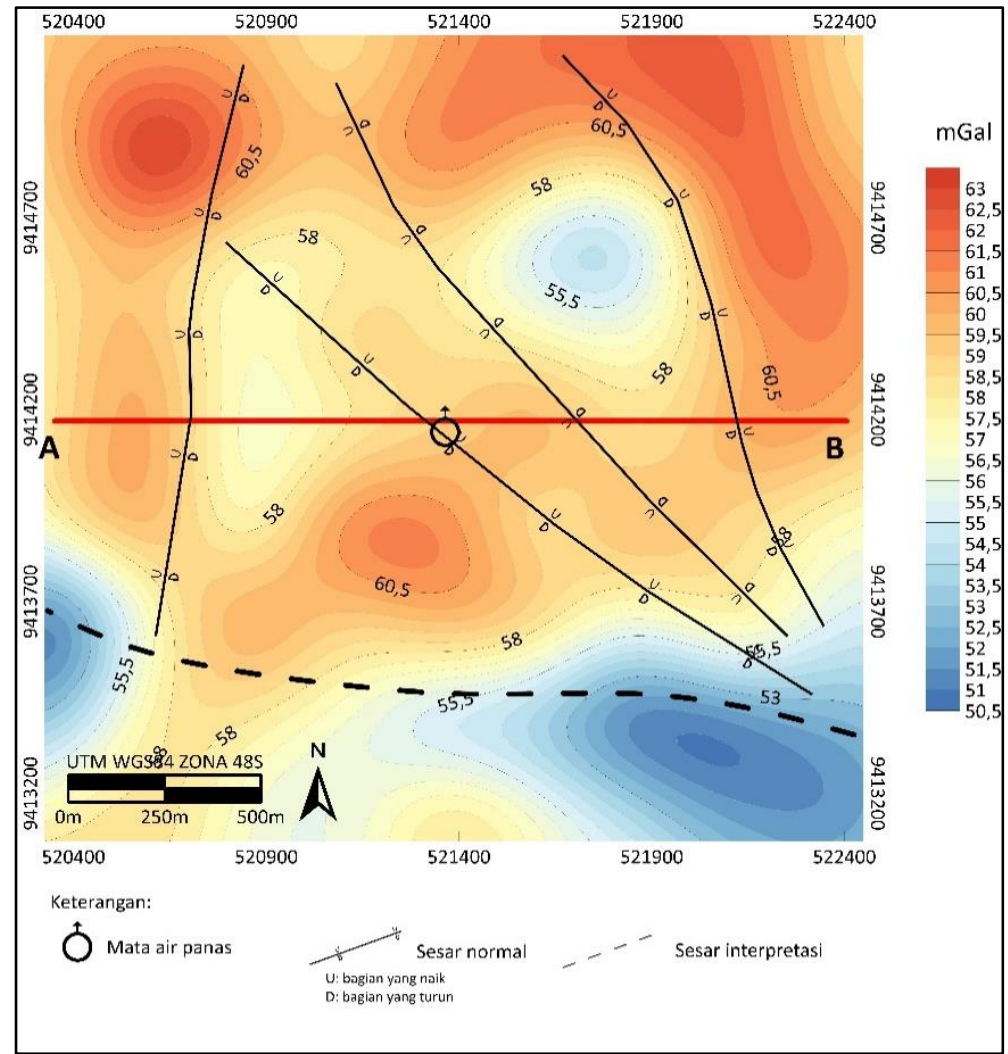

(c)

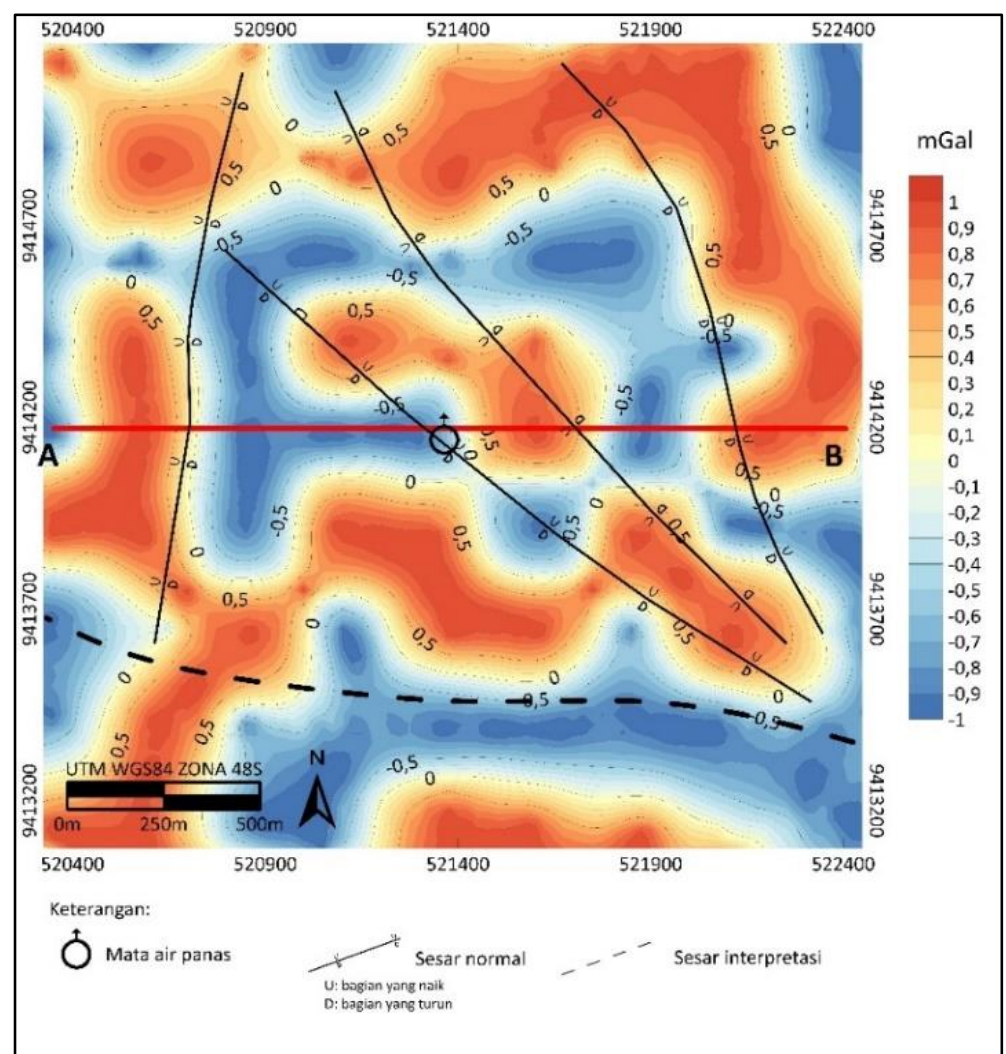

(d)

Gambar 5. Peta anomali gayaberat daerah Natar. (a) anomali Bouguer lengkap, (b) anomali regional, (c) anomali residual, (d) SVD 
Peta yang dihasilkan dari pengolahan data gayaberat (Gambar 5) menunjukkan beberapa wilayah yang memiliki kontras densitas yang signifikan. Dapat dilihat dengan jelas pada Gambar 5 (a-c) pada bagian tenggara memiliki nilai relatif yang rendah, sedangkan pada bagian timurlaut memperlihatkan nilai tinggi. Peta SVD (Gambar 5.d) juga memperlihatkan bagian selatan memiliki nilai yang rendah dan menerus ke sampai ke sisi timur. Selain itu, peta anomali Bouguer dan anomali regional juga menunjukkan bahwa bagian tengah daerah penelitian, yang merupakan tempat keluarnya mata air panas Natar, merupakan daerah rendah (menyerupai cekungan).

\section{PEMBAHASAN}

Dari beberapa peta yang dihasilkan, penulis menginterpretasi bahwa daerah penelitian memiliki beberapa struktur geologi berupa sesar normal (Gambar 5) yang berarah dominan baratlaut-tenggara (tiga sesar yang berada di tengah hingga ke timur daerah penelitian) dan utara-selatan (paling barat) dan satu sesar interpretasi berarah barat-timur pada bagian selatan daerah penelitian yang ditarik berdasarkan kelurusan yang dibentuk oleh nilai kontras densitas dari peta yang telah diperoleh.

Selanjutnya, pemodelan 2D dilakukan terhadap penampang $A-B$ untuk melihat distribusi batuan dan struktur bawah permukaan dengan menggunakan perangkat lunak Geosoft Oasis Montaj 8.4. Pemodelan 2D dilakukan dengan menggunakan asumsi dari data geologi regional (Mangga dkk., 1993) bahwa daerah penelitian memiliki tiga lapisan batuan yang terdiri dari dua lapisan batuan dasar (basement) yang merupakan batuan beku dan batuan metamorf dengan umur Paleozoikum-Kapur dengan densitas masing-masing $2,54 \mathrm{~g} / \mathrm{cm}^{3}$ dan 2,76 $\mathrm{g} / \mathrm{cm}^{3}$, dan lapisan batuan piroklastik berumur Kuarter berupa tuf-vulkanoklastik.

Pemodelan dilakukan dengan cara melakukan trial and error dengan mempertimbangkan densitas batuan serta struktur geologi yang ada di bawah permukaan sehingga nilai gayaberat terobservasi (observed) mendekati nilai terhitung (calculated) dan menghasilkan nilai error yang kecil (Gambar 6). Dari gambar tersebut dapat dilihat bahwa daerah penelitian memiliki struktur horst dan graben yang terbentuk akibat regime extentional pada masa Kuarter dan diperkirakan masih berkaitan dengan sistem Sesar Besar Sumatra. Penelitian sebelumnya yang dilakukan oleh lqbal dkk. (2019b) tentang hidrogeokimia fluida air panas Natar menunjukkan bahwa reservoir Natar memiliki temperatur $120-140^{\circ} \mathrm{C}$ dengan kedalaman sekitar $300 \mathrm{~m}$, sehingga struktur horst dan graben tersebut diperkirakan menjadi jalur keluarnya mata air panas Natar ke permukaan.

Dari perhitungan geotermometer, reservoir panas bumi di Natar tergolong ke dalam sistem dengan temperatur sedang sehingga kurang optimal jika digunakan untuk pembangkit listrik tenaga panas bumi. Pengembangan lebih lanjut lapangan panas bumi di Natar ini dapat digunakan sebagai pemandian air panas atau pengering tanaman seperti kopi, pisang, tomat, (Saptadji, 2018). Namun untuk mendapatkan temperatur yang diinginkan, diperlukan pengeboran air panas hingga mencapai reservoir yang ditargetkan. Titik pengeboran direkomendasikan dilakukan pada daerah graben/depresi (turunan) di sebelah barat dari mata air panas yang ada pada saat ini karena berdasarkan pemodelan geologi daerah tersebut diduga merupakan daerah reservoir panas bumi (Gambar 6 dan 7). 


\section{MAKALAH ILMIAH}

\section{Penampang A-B}

A
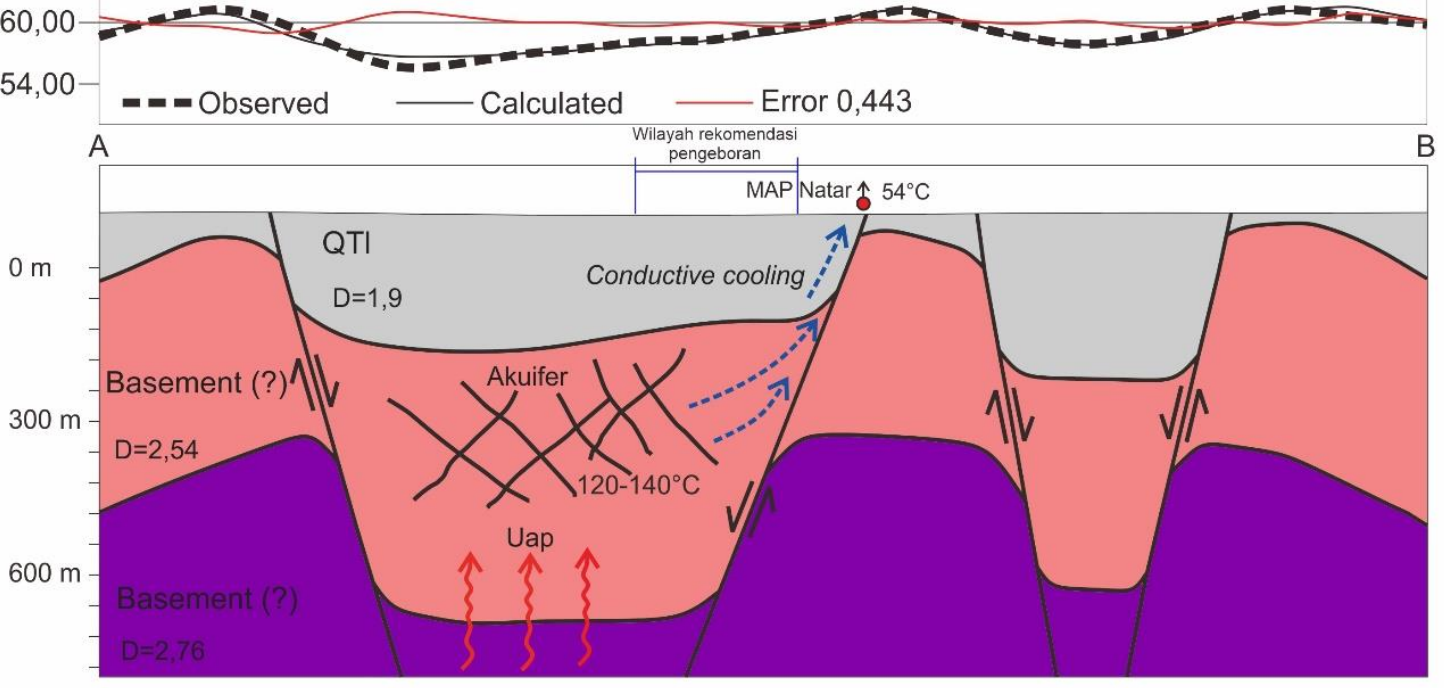

Gambar 6. Model struktur geologi lapangan panas bumi Natar berdasarkan pemodelan bawah permukaan data gayaberat

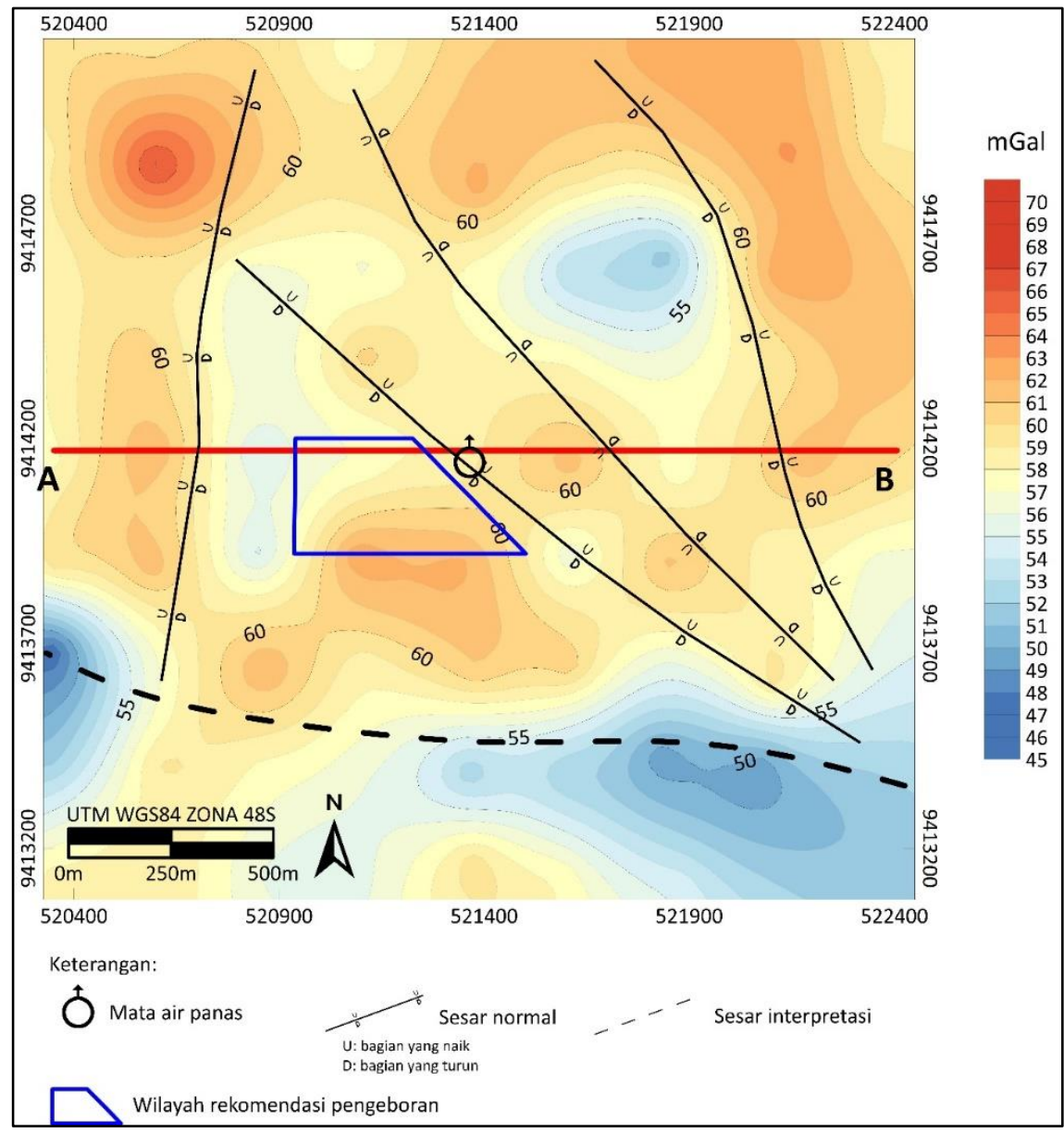

Gambar 7. Rekomendasi wilayah pengeboran daerah panas bumi Natar 


\section{KESIMPULAN DAN SARAN}

Kemunculan mata air panas Natar ke permukaan dipengaruhi oleh struktur geologi yang berupa sesar normal berarah utara-selatan dan baratlaut-tenggara yang membentuk struktur horst dan graben. Pemodelan bawah permukaan menunjukkan adanya tiga lapisan batuan yang menyusun daerah penelitian yaitu batuan piroklastik $\left(\rho=1,9 \mathrm{~g} / \mathrm{cm}^{3}\right.$, batuan beku $\rho=2,54 \mathrm{~g} / \mathrm{cm}^{3}$, dan batuan metamorf $\rho=2,76 \mathrm{~g} / \mathrm{cm}^{3}$. Pengeboran eksplorasi untuk penelitian selanjutnya disarankan dilakukan pada sebelah barat mata air panas untuk mengonfirmasi model bawah permukaan yang telah dihasilkan.

\section{UCAPAN TERIMA KASIH}

Penulis mengucapkan terima kasih kepada Kemenristekdikti yang telah mendanai penelitian ini sehingga penelitian ini dapat berjalan dengan baik. Kemudian penulis juga berterima kasih kepada Hikhmadhan Gultaf dan Alviyanda yang telah memberikan saran dan masukan terhadap tulisan ini.

\section{DAFTAR PUSTAKA}

Ditjen EBTKE, 2017. Potensi Panas Bumi Indonesia. Direktorat Panas Bumi, Direktorat Jenderal Energi Baru, Terbarukan dan Konservasi Energi, Kementerian Energi dan Sumber Daya Mineral, Jakarta.

Guglielmetti, L., Comina, C., Abdelfettah, Y., Schill, E., Mandrone, G., 2013. Integration of 3D geological modeling and gravity surveys for geothermal prospection in an Alpine region. Tectonophysics 608, 10251036.

https://doi.org/10.1016/j.tecto.2013. 07.012
Iqbal, M., Ashuri, W., Juliarka, B.R., Farishi, B.A., Harbowo, D.G., 2019a. Delineation of Recharge and Discharge Area for Geothermal Energy in Natar. IOP Conf. Ser. Earth Environ. Sci. 258, 012036. https://doi.org/10.1088/17551315/258/1/012036

Iqbal, M., Juliarka, B.R., Ashuri, W., Farishi, B.A., 2019b. Hydrogeochemistry of Natar and Cisarua Hot springs in South Lampung, Indonesia. J. Geosci. Eng. Environ. Technol. 4, 178-185.

https://doi.org/10.25299/jgeet.2019. 4.3.2959

Maithya, J., Fujimitsu, Y., Nishijima, J., 2020. Analysis of gravity data to delineate structural features controlling the Eburru geothermal system in Kenya. Geothermics 85, 101795.

https://doi.org/10.1016/j.geothermic s.2019.101795

Mangga, S.A., Amirudin, Suwarti, T., Gafoer, S., Sidarto, 1993. Peta Geologi Lembar Tanjungkarang, Sumatera skala 1:250.000.

Parasnis, D.S., Cook, A.H., 1952. A Study of Rock Densities in the English Midlands. Geophys. J. Int. 6, 252271. https://doi.org/10.1111/j.1365246X.1952.tb03013.X

Pocasangre, C., Fujimitsu, Y., Nishijima, J., 2020. Interpretation of gravity data to delineate the geothermal reservoir extent and assess the geothermal resource from low-temperature fluids in the Municipality of Isa, Southern Kyushu, Japan. Geothermics 83, 101735. https://doi.org/10.1016/j.geothermic s.2019.101735

Rymer, H., 2016. Gravity measurements on chips. Nature 531, 585-586. https://doi.org/10.1038/531585a 


\section{MAKALAH ILMIAH}

Saptadji, N., 2018. Teknik Geotermal, 1st ed. ITB Press, Bandung.

Soengkono, S., Bromley, C., Reeves, R., Bennie, S., Graham, D., 2013. Geophysical techniques for low enthalpy geothermal exploration in New Zealand. Explor. Geophys. 44, 215-227.

https://doi.org/10.1071/EG13036
Uwiduhaye, J. d'Amour, Mizunaga, H., Saibi, H., 2018. Geophysical investigation using gravity data in Kinigi geothermal field, northwest Rwanda. J. Afr. Earth Sci. 139, 184192.

https://doi.org/10.1016/j.jafrearsci.2 017.12.016

\begin{tabular}{|ll|}
\hline Diterima & $: 10$ Desember 2019 \\
Direvisi & $: 9$ Januari 2020 \\
Disetujui & $: 14$ Mei 2020 \\
\hline
\end{tabular}

